\title{
Macroheterocyclic Compound of ABBB-Type Containing 2N-Alkyl Substituted 1,2,4-Thiadiazoline Fragment: Synthesis and Acid-Base Properties
}

\author{
Yu. V. Butina, E. A. Danilova, ${ }^{@}$ T. V. Kudayarova, and A. S. Malyasova \\ Dedicated to Professor Oleg A. Golubchikov on the ocassion of his 70th Birthday \\ Ivanovo State University of Chemistry and Technology, Research Institute of Macroheterocycles, 153000 Ivanovo, Russian \\ Federation \\ ${ }^{\circledR}$ Corresponding author E-mail: danilova@isuct.ru
}

\begin{abstract}
The synthesis of ABBB-type macroheterocyclic compound containing both the 5-amino-2-dodecyl-3-imino-1,2,4-thiadiazoline fragment (fragment $A$ ) and three residues of 1,3-diiminoisoindoline (fragment B) is described in this work. The purification of target compound was carried out by column chromatography and by silica gel plate eluting with $\mathrm{CH}_{2} \mathrm{Cl}_{2}: \mathrm{MeOH}: \mathrm{C}_{6} \mathrm{H}_{14}$ mixture. The structure of the resultant compound was determined by data of $\mathrm{UV}$-Vis, IR, ${ }^{1} \mathrm{H}$ and ${ }^{13} \mathrm{C} N M R$ spectroscopy, and mass spectrometry. It was shown that the target product possesses unique stability in acid medium and can belong to the class of "molecular chameleons" due to its ability postsynthetic modification of the optical properties of molecule. A bathochromic shift of the absorption maximum at 459-555 $\mathrm{nm}$ and emergence of new inflection points at 692 and $721 \mathrm{~nm}$ in trifluoroacetic acid and a shift to $716 \mathrm{~nm}$ in sulfuric acid were observed in the UV-visible spectrum. Acid-base behavior has been studied by spectrophotometric titration method in two solvent systems: $\mathrm{CH}_{2} \mathrm{Cl}_{2}-\mathrm{CF}_{3} \mathrm{COOH}$ and $\mathrm{C}_{2} \mathrm{H}_{5} \mathrm{OH}-\mathrm{H}_{2} \mathrm{SO}_{4}$. The study of protonation in the first solvent system shows an interaction between one molecule of the macroheterocycle with one molecule of the acid. Investigations of the second medium demonstrated the presence of one non-protonated $(\lambda=478 \mathrm{~nm})$ and two protonated $(\lambda=550 \mathrm{~nm}, \lambda=716 \mathrm{~nm})$ forms. The most possible position of protonation was determined by quantum chemical calculations at the DFT level.
\end{abstract}

Keywords: Macroheterocycle of ABBB-type, 1,2,4-thiadiazoline, 1,3-diiminoisoindoline, spectroscopy, molecular chameleon.

\section{Макрогетероциклическое соединение АВВВ-типа, содержащее фрагмент $2 N$-алкилированного 1,2,4-тиадиазолина: синтез и кислотно-основные свойства}

\author{
Ю. В. Бутина, Е. А. Аанилова, ${ }^{\circledR}$ Т. В. Кудаярова, А. С. Малясова \\ Посвящается профессору О. А. Голубчикову по случаю его 70-летнего юбилея
}

Ивановский государственный химико-технологический университет, НИИ химии макрогетерочиклических соединений, 153000 Иваново, Российская Федерация

@E-mail: danilova@isuct.ru

\footnotetext{
В работе описывается синтез макрогетерочиклического соединения АВВВ-типа, содержащего фрагмент 5-амино-2-додецил-3-имино-1,2,4-тиадиазолина (фрагмент А) и три остатка 1,3-дииминоизоиндолина (фрагмент В). Очистку иелевого соединения осуществляли колоночной с последующей препаративной хроматографией на пластинах силикагеля, элюируя смесью $\mathrm{CH}_{2} \mathrm{Cl}_{2}: \mathrm{MeOH}: \mathrm{C}_{6} \mathrm{H}_{14}$. Строение полученного соединения доказано данныли электронной, ИК, ${ }^{1} \mathrm{H}$ и ${ }^{13} \mathrm{C}$ ЯМР спектроскопии, масс-спектрометрии. Показано, что ичелевой продукт обладает уникальной стабильностью в кислой среде и может быть отнесен к классу
} 
«молекулярных хамелеонов» из-за его способности к постсинтетической модификаџии оптических свойств молекульл. В среде трифторуксусной кислоты наблюдаются батохромный сдвиг максимума поглощзения от 459 до 555 нм и появление небольших инфлексий при 692 и 721 нм, в среде серной кислоть - сдвиг до 716 нм. Кислотно-основные свойства изучены методом спектрофотометрического титрования в двух системах: $\mathrm{CH}_{2} \mathrm{Cl}_{2}-\mathrm{CF}_{3} \mathrm{COOH}$ и $\mathrm{C}_{2} \mathrm{H}_{5} \mathrm{OH}-\mathrm{H}_{2} \mathrm{SO}_{4}$. Изучение протонирования в первой среде показало, что на первой стадии происходит взаимодействие одной молекуль макрогетероичикического соединения с одной молекулой кислоты. Исследования во второй среде продемонстрировало сущчествование одной непротонированной $(\lambda=478$ нм) и двух протонированных ( $\lambda=550 \mathrm{нм}, \lambda=716 \mathrm{нм}$ ) форм. Наиболее вероятное место присоединения протона определяли с использованием методов квантовой химии на уровне DFT.

Ключевые слова: Макрогетероцикл АВВВ-типа, 1,2,4-тиадиазолин, 1,3-дииминоизоиндолин, спектроскопия, молекулярные хамелеоны.

\section{Introduction}

Recently, the development of methods of synthesis of hydrogenated derivatives of porphyrins is of special interest for researchers. These compounds, such as chlorins and bacteriochlorins, absorb light in the long-wave region of the spectrum due to changing of the symmetry upon the reduction of one or two double bonds while retaining of aromaticity. In the Russian Federation, sensitizers for photodynamic therapy of oncological diseases have been approved, i.e. Fotoditazin, ${ }^{[1,2]}$ Radahlorin, ${ }^{[3]}$ Photolon, ${ }^{[4]}$ which are water-soluble chlorin $e_{6}$ salts. The difficulty of synthesis of such compounds lies in the reduction of porphyrins, which results in the formation of a mixture of chlorins and bacteriochlorins. ${ }^{[5]}$

The syntheses of ABBB- and ABAB-type macroheterocyclic compounds, where $\mathrm{A}$ is a fragment of $2 \mathrm{~N}$-substituted 5-amino-3-imino-1,2,4-thiadiazoline, and $\mathrm{B}$ is the residue of 1,3-diiminoisoindoline, are of interest. Such products will possess tetrazachlorin- and tetrazabacteriochlorin-like structures (Figure 1) due to the presence of the $2 N$-substituted 1,2,4-thiadiazoline moiety. We have not found a description of these compounds in the literature. For our proposed

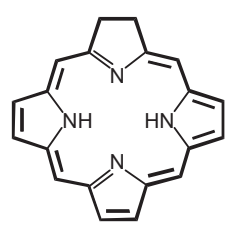

Chlorin

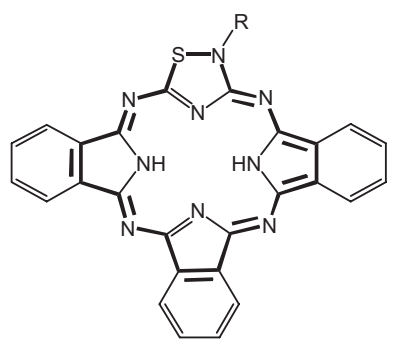

Tetraazaclorin-like compound

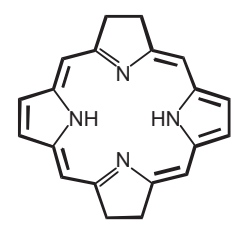

Bacteriochlorin

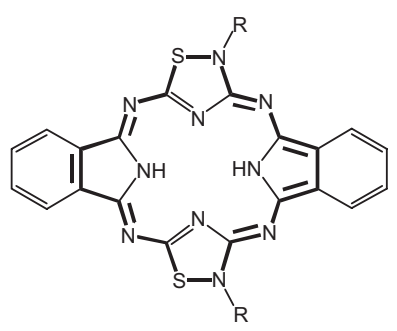

Tetraazabacteriochlorin-like compound
Figure 1. Chromophore system of conjugated double bonds in chlorin, bacteriochlorin and similar compounds. syntheses, a decrease in the number of synthetic steps and the time of synthesis are expected. This phenomenon can be explained by the formation of a chlorin or bacteriochlorin-like structure without the reduction of one or two double bonds in the macrocycle, which leads to the formation of a mixture of di- and tetrahydrogenated products.

It can be expected that the absorption maximum of such compounds will be shifted to the near-IR region in an analogous fashion as with chlorins and bacteriochlorins, which will allow them to be considered as photosensitizers. Therefore, this work attempts to synthesize of a chlorin-like macrocyclic compound containing a fragment of $2 \mathrm{~N}$-dodecylsubstituted 1,2,4-thiadiazoline.

\section{Experimental}

\section{Methods}

Research on the synthesized compound was carried out using the resources of the Center for Collective Use of Scientific Equipment of Ivanovo State University of Chemistry and Technology. UV-Vis spectra were measured using a HITACHI U-2001 spectrometer in quartz cells of thickness 2 and $10 \mathrm{~mm}$. IR spectra were obtained with AVATAR 360 FT-IR spectrometer with a diffusion reflection attachment Tensor 27 Bruker Optics. The samples were prepared by carefully triturating of the synthesized compound with $\mathrm{KBr}$ and compression of the tablet. MALDI-TOF mass spectra were recorded on the AXIMA Confidence (SHIMADZU) instrument in the positive ion detection mode. Samples were prepared by dissolving of the synthesized compound in chloroform $\left(C=10^{-4}-10^{-6} \mathrm{~mol} \cdot \mathrm{L}^{-1}\right)$. DHB is 2,5-dihydroxybenzoic acid, which was used as a matrix. Nuclear magnetic resonance spectra $\left({ }^{1} \mathrm{H}\right.$ and $\left.{ }^{13} \mathrm{C}\right)$ were registered using a Bruker DRX-500 and an AVANCE-300 spectrometers from Bruker, respectively. Working frequencies are $500\left({ }^{1} \mathrm{H}\right)$ and $75.5\left({ }^{13} \mathrm{C}\right) \mathrm{MHz}$. Samples were prepared by dissolving the explored compound in $\mathrm{CDCl}_{3}$. Thin layer chromatography (TLC) was carried out on aluminum plates coated with a $60 \mathrm{~F}_{254}(\mathrm{E}$. Merck) silica gel layer. Silica gel of 60 0.05-0.20 mm (MachereyNagel) was used for column chromatography.

\section{Synthesis}

2-Dodecyl-3,10,17,24-tetraimino-5,12,19,26-tetranitrilo1-thiotribenzo[f,k,p](1,5,9,13)tetraazacyclohexadecene (1) was obtained by the reaction of $0.26 \mathrm{~g}(0.91 \mathrm{mmol})$ of 5-amino-2-dodecyl3-imino-1,2,4-thiadiazoline (2), synthesized by method described in the literature, ${ }^{[6]}$ and $0.4 \mathrm{~g}(2.74 \mathrm{mmol})$ of 1,3-diiminoisoindoline in $3 \mathrm{~mL}$ of phenol with step-by-step heating during 1.5-2 hours. 
The reaction mixture was stirred for 50 hours at temperature 100$110{ }^{\circ} \mathrm{C}$, then the product was washed by hot water and hexane in Soxlet apparatus while absence of phenol, which was determined by qualitative reaction with ferric chloride. The target product was purified by column chromatography with following preparative thin layer chromatography on plates of silica gel eluting with a mixture of $\mathrm{CH}_{2} \mathrm{Cl}_{2}: \mathrm{MeOH}: \mathrm{C}_{6} \mathrm{H}_{14}=10: 1: 3$. A bright-burgundy band was collected, the target compound was washed with acetone for removed of silica gel, and the solvent was evaporated in vacuo.

The product is dark-cherry powder. Yield: $7 \mathrm{mg}$ (3.7\%). M.p. $>200{ }^{\circ} \mathrm{C} . \mathrm{m} / z$ (MALDI-TOF) $690.6[\mathrm{M}+\mathrm{K}]^{+}$. EM 651.3. $\mathrm{C}_{38} \mathrm{H}_{37} \mathrm{~N}_{9} \mathrm{~S}$. IR $(\mathrm{KBr}) v_{\max } \mathrm{cm}^{-1}: 3437,2925,2853$ val $\left(\mathrm{C}-\mathrm{H}^{\text {alk }}\right), 1739,1647$, 1556 val $(\mathrm{C}=\mathrm{N}), 1461$ val $\left(\mathrm{C}-\mathrm{C}^{\text {ar }}\right), 1378,1264,1091,875,713$. UVVis $\left(\mathrm{C}_{2} \mathrm{H}_{5} \mathrm{OH}, C=6.12 \cdot 10^{-5} \mathrm{~mol} \cdot \mathrm{L}^{-1}\right) \lambda_{\max }(\lg \varepsilon) \mathrm{nm}: 263(4.41), 480$ (3.60); (benzene, $\left.C=3.06 \cdot 10^{-5} \mathrm{~mol} \cdot \mathrm{L}^{-1}\right) \lambda_{\max }(\lg \varepsilon) \mathrm{nm}: 451$ (3.70); (acetone, $\left.C=1.49 \cdot 10^{-3} \mathrm{~mol} \cdot \mathrm{L}^{-1}\right) \lambda_{\max }(\lg \varepsilon) \mathrm{nm}: 457(2.85) ;\left(\mathrm{CH}_{2} \mathrm{Cl}_{2}\right.$, $\left.C=5.43 \cdot 10^{-4} \mathrm{~mol} \cdot \mathrm{L}^{-1}\right) \lambda_{\max }(\lg \varepsilon) \mathrm{nm}: 453$ (3.25); $\left(\mathrm{CH}_{3} \mathrm{COOH}\right.$, $\left.C=3.06 \cdot 10^{-5} \mathrm{~mol} \cdot \mathrm{L}^{-1}\right) \lambda_{\max }{ }^{\max }(\lg \varepsilon) \mathrm{nm}: 478$ (3.32); $\left(2,2,2-\mathrm{CF}_{3} \mathrm{COOH}\right.$, $\left.C=4.16 \cdot 10^{-4} \mathrm{~mol} \cdot \mathrm{L}^{-1}\right) \lambda_{\text {max }}(\lg \varepsilon) \mathrm{nm}: 555$ (3.38), 692 (2.94), 721 (2.92). ${ }^{1} \mathrm{H}$ NMR $\left(\mathrm{CDCl}_{3}\right) \delta_{\mathrm{H}}$ ppm: 7.90-7.77 (m, 12 $\left.\mathrm{H}_{\mathrm{ar}}\right), 1.59-0.89$ $\left(25 \mathrm{H}_{\mathrm{alk}}\right) \cdot{ }^{13} \mathrm{C} \mathrm{NMR}\left(\mathrm{CDCl}_{3}\right) \delta_{\mathrm{C}} \mathrm{ppm}: 170.33(\mathrm{C} 14), 168.50(\mathrm{C} 13)$, 134.30 (C15), 132.77 (C16), 123.58 (C17), 121.49 (C18), 63.11 (C12), 50.82 (C11), 31.93 (C10), 31.81 (C9), 31.37 (C8), 30.53 (C7), 29.64 (C6), 29.62 (C5), 29.36 (C4), 25.80 (C3), 22.70 (C2), 14.13 (C1). The numbers of carbon atoms are shown in Figure 6.

\section{Results and Discussion}

\section{Synthesis}

To date, a number of macroheterocyclic compounds with an asymmetrical (ABBB-type) structure containing fragments of 3,5-diamino-1,2,4-triazoles ${ }^{[7,8]}$ and 2,5-diamino-1,3,4-thiadiazoles ${ }^{[9]}$ is known. However, the compounds that contain the 3,5-diamino-1,2,4thiadiazole fragment remain insufficiently known. We obtained an ABBB-type macroheterocyclic compound containing the fragment of $2 \mathrm{~N}$-dodecyl substituted 5 -amino- 3-imino-1,2,4-thiadiazoline. The synthesis of this product was performed according to the Scheme below.

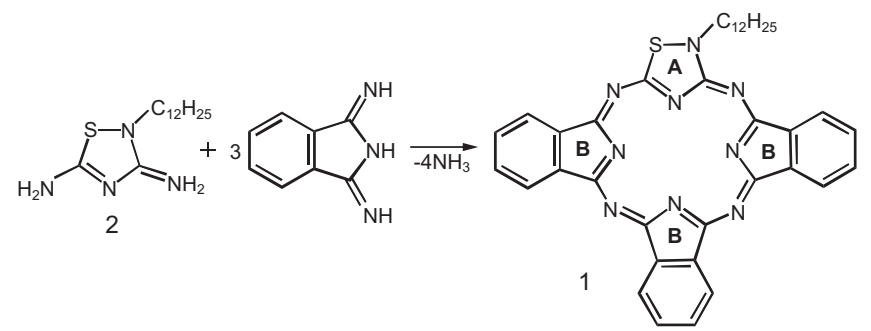

Scheme. Synthesis of an ABBB-type macroheterocyclic compound containing 5-amino-2-dodecyl-3-imino-1,2,4-thiadiazoline fragment.

The product 1 was obtained by the reaction of 5-amino2-dodecyl-3-imino-1,2,4-thiadiazoline with 1,3-diiminoisoindoline in phenol at $100-110{ }^{\circ} \mathrm{C}$ over 50 hours. The reaction of the target compound was observed to be unselective. The purification was not sufficient by a column method, and repeated use of this method was impossible because of the instability of the compound obtained. Therefore, product 1 was isolated using preparative chromatography.

Compound 1 was characterized by mass spectrometry, UV-Vis, IR, ${ }^{1} \mathrm{H}$ and ${ }^{13} \mathrm{C}$ NMR spectroscopy. The mass spectrum of 1 contains a signal with $\mathrm{m} / \mathrm{z}$ 690.6 Da corresponding to molecular ion in form $[\mathrm{M}+\mathrm{K}]^{+}$. The isotopic distribution corresponds to the theoretically calculated: $690.3-100 \%$, 691.3-41.1 \%, 692.3-7.2 \% (Figure 2).

In the IR spectrum bands at 2925 and $2853 \mathrm{~cm}^{-1}$ can be assigned to stretching valence $\mathrm{C}-\mathrm{H}$ vibrations of the alkyl group, with bands at 1556 and $1481 \mathrm{~cm}^{-1}$ characterized as stretching valence $\mathrm{C}=\mathrm{N}$ and $\mathrm{C}-\mathrm{C}$ bonds of the heterocyclic fragments.

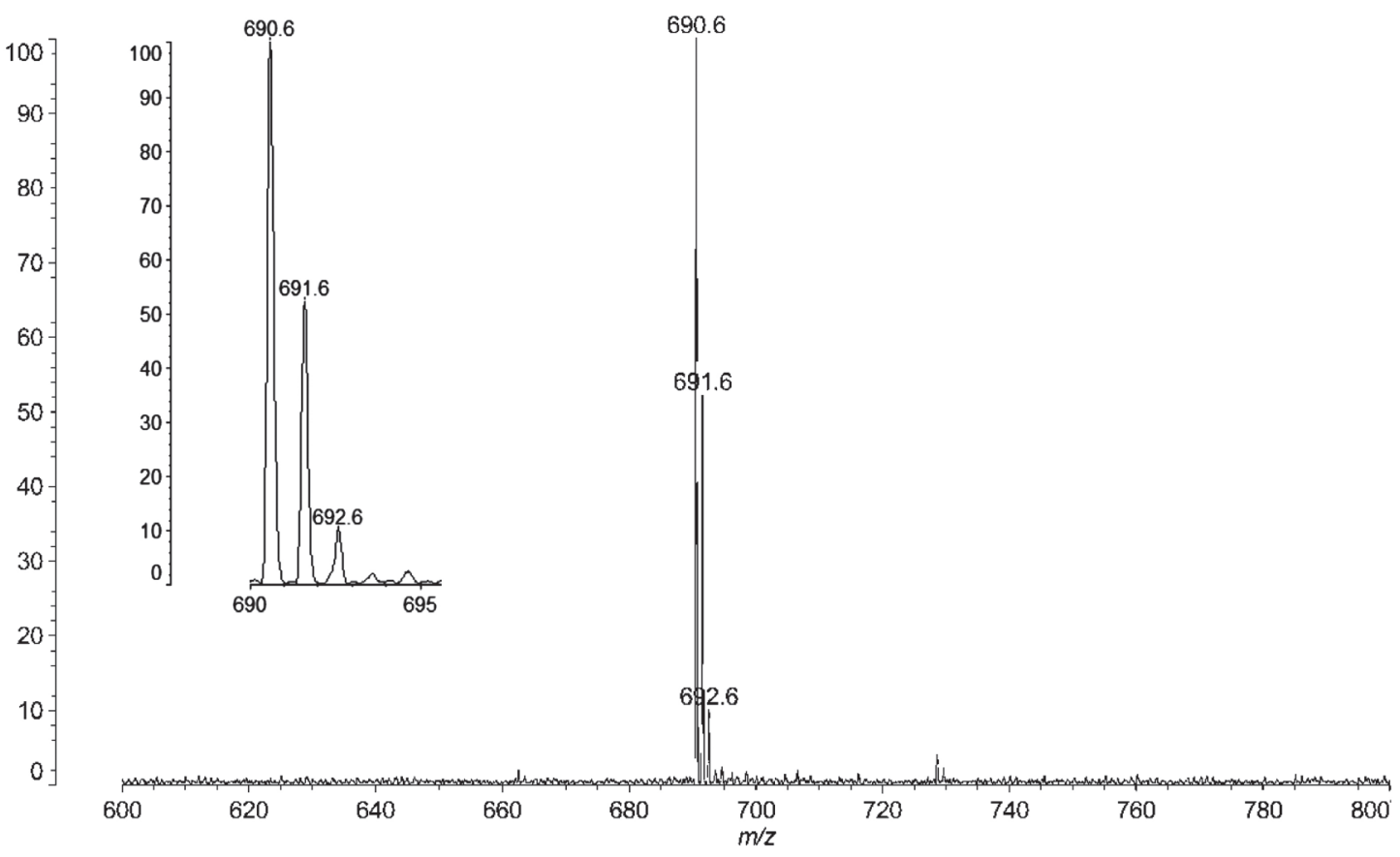

Figure 2. The fragment of mass spectrum of compound $\mathbf{1}$. 
There is an absorption maximum at $\lambda=263 \mathrm{~nm}$ in the UV-Vis spectrum recorded in ethanol, which indicates the presence of the thiadiazole ring. The nature of the spectrum in the visible region with $\lambda_{\max }=480 \mathrm{~nm}$ is similar to that of the ABBB-type macroheterocyclic compounds containing the 1,3,4-thiadiazole moiety. ${ }^{[10]} \mathrm{A}$ hypsochromic shift of the absorption maximum occurs with a decrease in the polarity of the solvent. Thus, the absorption maximum appears in the region of 457, 453, $451 \mathrm{~nm}$ in acetone, dichloromethane, and benzene, respectively.

Figure 3 shows, that broadening of the long-wave absorption band occurs in the UV-Vis spectrum recorded in acetone upon dilution of a solution of $\mathbf{1}$. The dependence of the absorption intensity on the solution concentration is linear (Figure 4). Consequently, the Lambert-BouguerBeer law is observed within the limits of concentrations $(5.77-14.9) \cdot 10^{-4} \mathrm{~mol} \cdot \mathrm{L}^{-1}$. The same dependence is also observed for solutions in dichloromethane and ethanol.

In the ${ }^{1} \mathrm{H}$ NMR spectrum of compound 1, recorded in deuterochloroform, there is a multiplet in the range

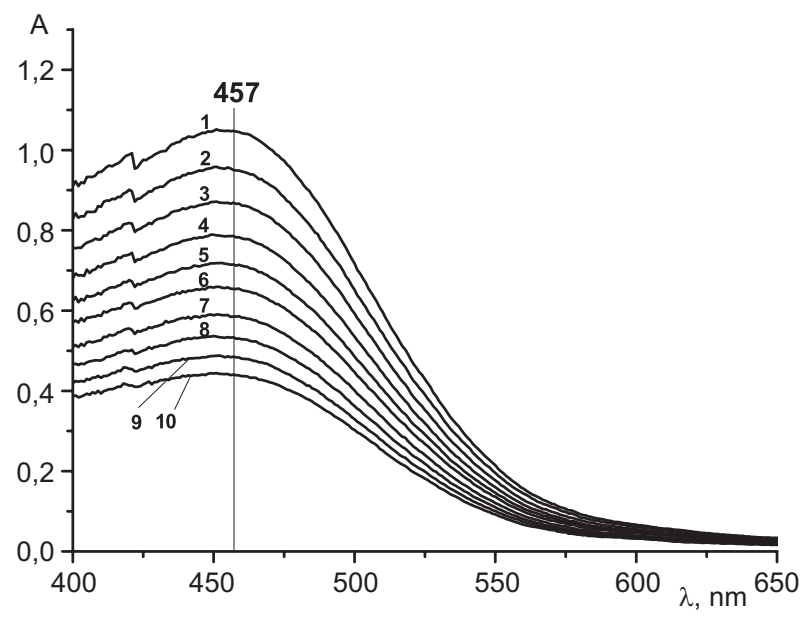

Figure 3. UV-Vis spectra of $\mathbf{1}$ (acetone, $C \cdot 10^{4}, \mathrm{~mol} \cdot \mathrm{L}^{-1}$ ): $\mathbf{1}-14.9$; $\mathbf{2}-13.4 ; \mathbf{3}-12.1 ; \mathbf{4}-10.8 ; \mathbf{5}$ - 9.76; 6 - 8.79; 7 - 7.91; 8 - 7.12; 9-6.41; 10-5.77.

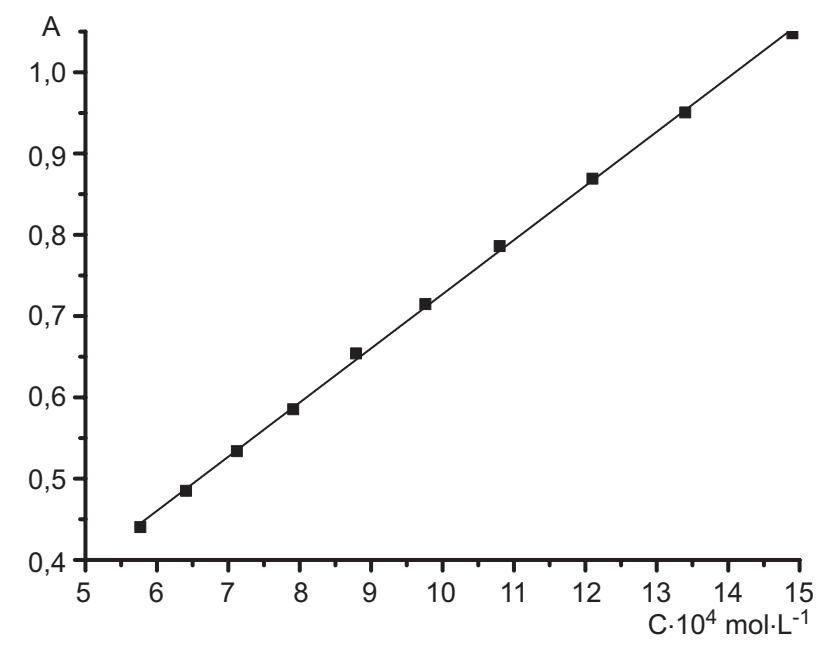

Figure 4. Dependence of optical density on concentration of $\mathbf{1}$ (acetone, $\lambda_{\max }=457 \mathrm{~nm}$ ). Squares are an experiment, the line is the least-squares calculation $( \pm 0.005$, probability P 0.99$)$. of 7.90-7.77 ppm, which characterizes the resonance of the protons from the aromatic fragments. Theoretically, the signals of the protons of the isoindole residue should be observed in the form of 2 doublets, which are formed due to the spin-spin interaction of protons $\mathrm{H}^{\mathrm{a}}$ and $\mathrm{H}^{\mathrm{b}}$ (Figure 5). The presence of a multiplet can be explained by the asymmetry of molecule $\mathbf{1}$, because of which the protons of aromatic fragments are unequal. The overlapping of several doublets forms a complex system of multiplets, whose type couldn't be determined and calculation of the spin-spin coupling constant wasn't possible. Signals in the region of 1.59-0.89 ppm correspond to the resonance of the protons of the alkyl substituent. In the region of 11.5-12.5 ppm signals are not observed, which indicates the absence of protons at the intracyclic nitrogen atoms of isoindole fragments. ${ }^{[11]}$ This phenomenon is also confirmed experimentally: when interacting with nickel acetate, compound $\mathbf{1}$ does not coordinate the metal atom. Therefore, our expectations of obtaining a compound similar hydrogenated porphyrazine were unsuccessful.

The ${ }^{13} \mathrm{C}$ NMR spectrum of $\mathbf{1}$ reveals the signals in the region $170.33,168.50 \mathrm{ppm}$, which characterize the resonance carbon atoms of thiadiazole fragment. The signals in the region $134.30,132.77,123.58,121.49$ ppm can be assigned to carbon atoms of isoindole residue. The signals at 63.11, 50.82, 31.93, 31.81, 31.37, 30.53, 29.64, 29.62, 29.36, $25.80,22.70,14.13 \mathrm{ppm}$ confirm presence of twelve carbon atoms of alkyl group (Figure 6).

\section{Acid-base behavior}

Porphyrazines are multicenter conjugate bases due to the presence in their structure of donor centers: intra-cyclic and peripheral nitrogen atoms. The stability of porphyrazines is determined by the existence of a neutral or acidic form of these compounds in a proton-donor medium. The number of donor centers participating in the acid-base interaction depends on the proton-donor medium and on the structure of the protonated molecule.

We have studied the stability of product $\mathbf{1}$ in acidic media, which is similar in structure to hydrogenated porphyrazine $\mathbf{3}$, in which there are no hydrogen atoms in the inside cavity.

When solution of compound $\mathbf{1}$ is added to trifluoroacetic acid, a bathochromic shift of the absorption maximum is observed from $459 \mathrm{~nm}$ in dichloromethane to 555 $\mathrm{nm}$ in $\mathrm{CF}_{3} \mathrm{COOH}$. Moreover, small inflections appear at 692 and $721 \mathrm{~nm}$ (Figure 7). When dissolving of 1 in monohydrate, the absorption maximum is bathochromatically shifted to the region of $611 \mathrm{~nm}$ (Figure 8). All these phenomena support the protonation of compound $\mathbf{1}$.

A determination of the number of donor centers involved in acid-base interaction is possible when performing spectrophotometric titration in media with a known acidity function. However, to determine the concentration stability constants, an investigation of $\mathbf{1}$ was carried out using two mixtures: $\mathrm{CH}_{2} \mathrm{Cl}_{2}-\mathrm{CF}_{3} \mathrm{COOH}$ and $\mathrm{C}_{2} \mathrm{H}_{5} \mathrm{OH}-\mathrm{H}_{2} \mathrm{SO}_{4}$, for which the acidity functions are unknown. In the absence of the latter, the titration data do not allow us to determine the number of donor centers, but only show the number of acid molecules participating in the protonation reaction. 


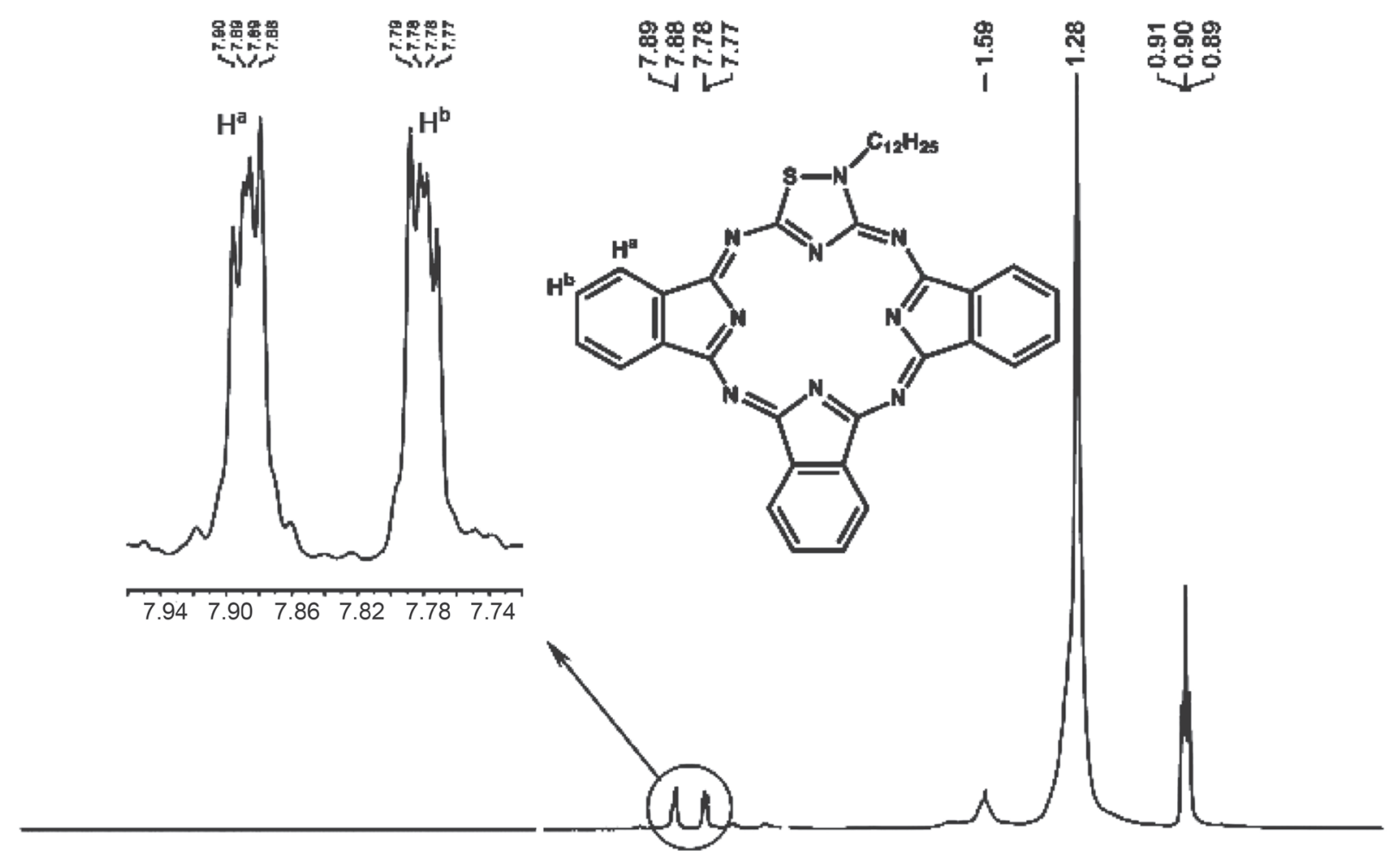

$\begin{array}{lllllllllllllllllllllllllllllll}12.6 & 12.4 & 12.2 & 12.0 & 11.8 & 11.6 & 11.4 & 11.2 & 11.0 & 8.2 & 8.0 & 7.8 & 7.6 & 2.2 & 2.0 & 1.8 & 1.6 & 1.4 & 1.2 & 1.0 & 0.8 & 0.6 & 0.4 & \mathrm{ppm}\end{array}$

Figure 5. ${ }^{1} \mathrm{H}$ NMR spectrum of compound 1.
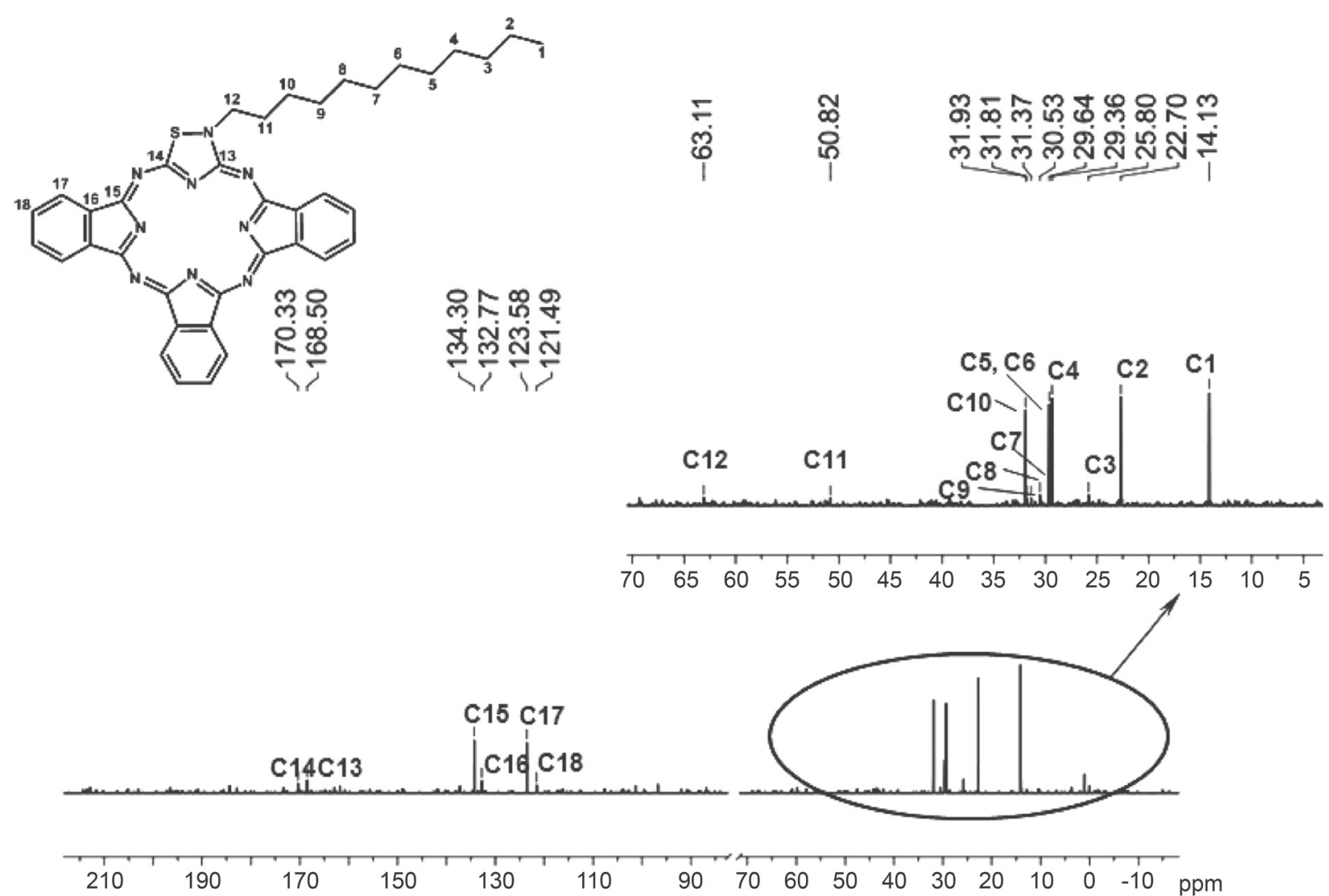

Figure 6. ${ }^{13} \mathrm{C}$ NMR spectrum of compound 1 . 


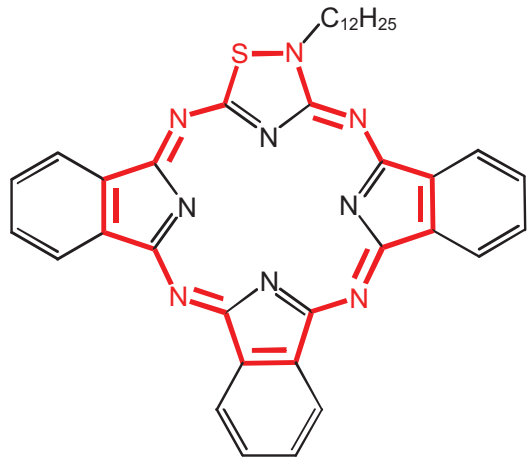

1

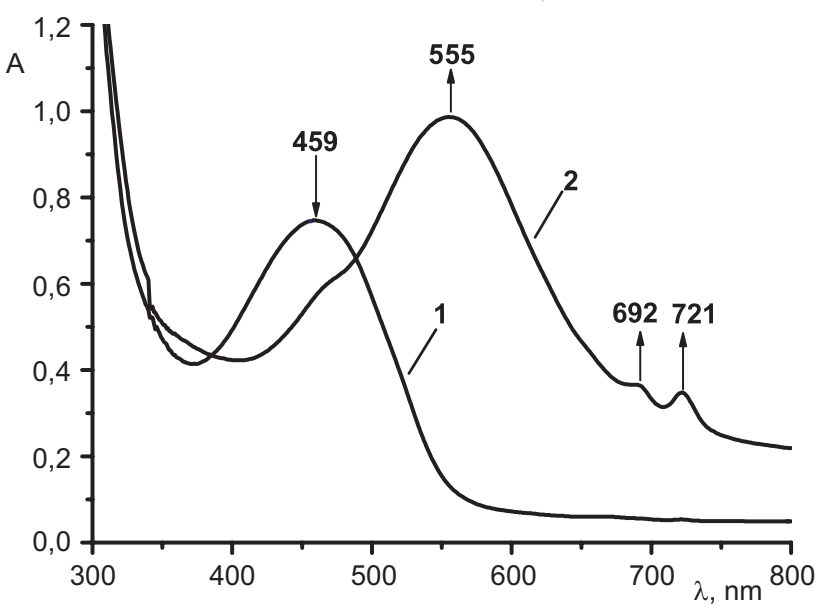

Figure 7. UV-Vis spectrum of compound 1: $1-\mathrm{CH}_{2} \mathrm{Cl}_{2}$ $\left(C=1.49 \cdot 10^{-4} \mathrm{~mol} \cdot \mathrm{L}^{-1}\right) ; 2-\mathrm{CF}_{3} \mathrm{COOH}\left(C=1.49 \cdot 10^{-4} \mathrm{~mol} \cdot \mathrm{L}^{-1}\right)$.

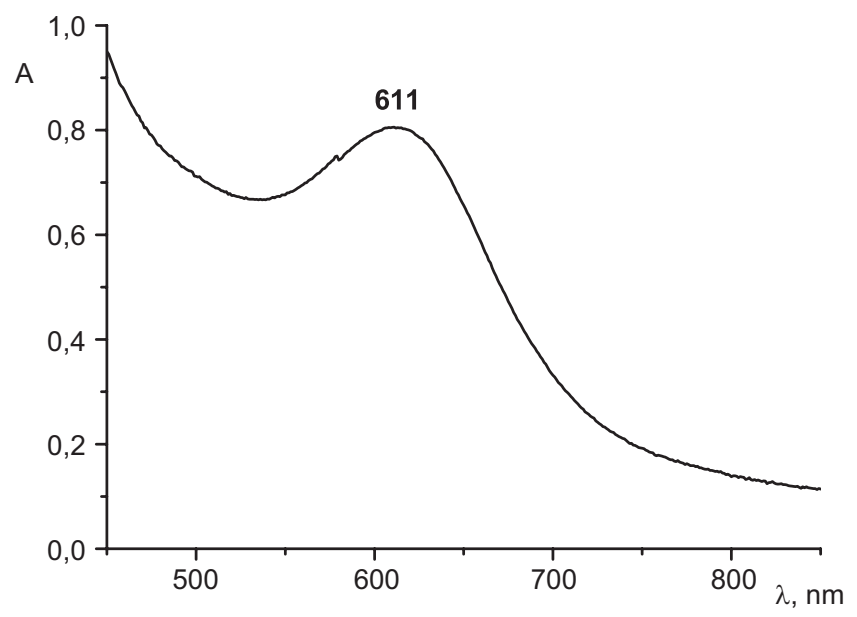

Figure 8. UV-Vis spectrum of compound 1 (monohydrate, $C=1.49 \cdot 10^{-4} \mathrm{~mol} \cdot \mathrm{L}^{-1}$ ).

When compound $\mathbf{1}$ is acidified in dichloromethane with trifluoroacetic acid (TFA) in the concentration range of $\mathrm{CF}_{3} \mathrm{COOH} 0.0013-0.6165 \mathrm{~mol} \cdot \mathrm{L}^{-1}$, characteristic changes are observed in the electronic absorption spectra accompanying the formation of acidified forms. In the first stage of this acid-base interaction $\left(C_{\mathrm{TFA}}=0.0013-0.0588 \mathrm{~mol} \cdot \mathrm{L}^{-1}\right)$, the intensity of the absorption maximum at $\lambda=459 \mathrm{~nm}$ gradually decreases, and at the same time a new band appears at $\lambda=523 \mathrm{~nm}$. This protonated form is kept to a concentration of $\mathrm{CF}_{3} \mathrm{COOH}$ equal to $0.0875 \mathrm{~mol} \cdot \mathrm{L}^{-1}$. The concentration stability constant of the resulting acidified form according to the transformed Hammett equation $\left(\mathrm{p} K_{\mathrm{si}}=\lg I_{\mathrm{i}}-\mathrm{nlg} C_{\mathrm{TFA}}\right)$ is equal to $1.84 \pm 0.01$.

It is known that the number of acid molecules participating in the interaction is equal to the tangent of the slope angle of the linear relationship $\mathrm{p} K_{\mathrm{si}}=f\left(\lg C_{\mathrm{TFA}}\right)$. For this interaction, $\operatorname{tg} \alpha$ is equal to 1.26 , which indicates the participation of one molecule of acid in the first stage of protonation. The value of $\operatorname{tg} \alpha$ is greater than 1 due to the homoconjugation phenomenon, in which the $\mathrm{CF}_{3} \mathrm{COO}^{-}$-anion is stabilized by the formation of conjugates with one or more acid molecules: $=\mathrm{NH}^{+} \ldots \mathrm{OOCCF}_{3}\left(\mathrm{CF}_{3} \mathrm{COOH}\right)_{\mathrm{n}}$, as well as the solvation of the macroheterocyclic compound.

An increase in the amount of $\mathrm{CF}_{3} \mathrm{COOH}$ to 0.6165 $\mathrm{mol} \cdot \mathrm{L}^{-1}$ leads to a further bathochromic shift of the absorption maximum, which indicates a stronger acid-base interaction $\mathbf{1}$ in this medium, but a second isosbestic point could not be determined. Thus, the study of properties of 1 in the $\mathrm{CH}_{2} \mathrm{Cl}_{2}-$ $\mathrm{CF}_{3} \mathrm{COOH}$ medium (Figure 9) made it possible to establish that in the first stage, interaction of $\mathbf{1}$ with one molecule of acid is observed.

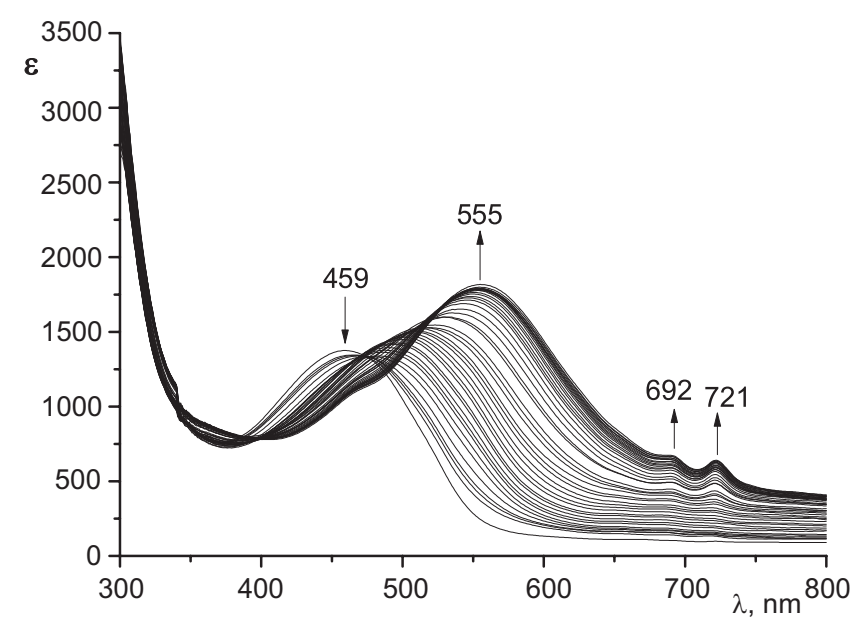

Figure 9. Changes in the UV-Vis spectrum of compound $\mathbf{1}$ in the system $\mathrm{CH}_{2} \mathrm{Cl}_{2}-\mathrm{CF}_{3} \mathrm{COOH}$. 


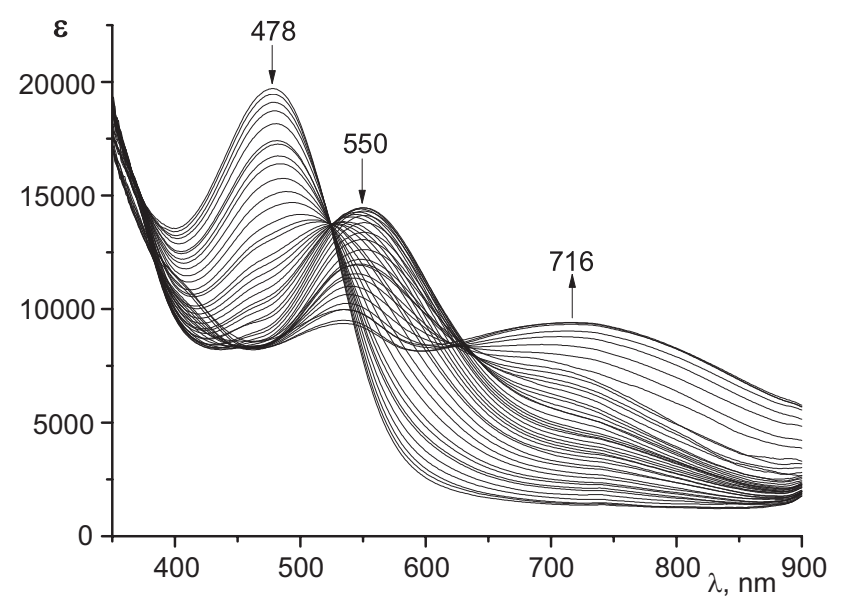

Figure 10. Changes in the UV-Vis spectrum of compound $\mathbf{1}$ in the system $\mathrm{C}_{2} \mathrm{H}_{5} \mathrm{OH}-\mathrm{H}_{2} \mathrm{SO}_{4}$.

Investigation of acid-base behavior of 1 was continued by spectrophotometric titration in media of $\mathrm{C}_{2} \mathrm{H}_{5} \mathrm{OH}-\mathrm{H}_{2} \mathrm{SO}_{4}$ (Figure 10), which showed existence of a non-protonated $(\lambda=478 \mathrm{~nm})$ and two protonated $(\lambda=550 \mathrm{~nm}, \lambda=716 \mathrm{~nm})$ forms.

Spectral changes in compound $\mathbf{1}$ were observed in the $\mathrm{C}_{2} \mathrm{H}_{5} \mathrm{OH}-\mathrm{H}_{2} \mathrm{SO}_{4}$ system over the concentration range of $\mathrm{H}_{2} \mathrm{SO}_{4}$ equaled $0.3596-15.4098 \mathrm{~mol} \cdot \mathrm{L}^{-1}$. In the first stage of the acid-base interaction $\left(C_{\mathrm{H} 2 \mathrm{SO} 4}=0.3596-2.8952 \mathrm{~mol} \cdot \mathrm{L}^{-1}\right)$, the intensity of the absorption maximum decreases and its bathochromic shift is $72 \mathrm{~nm}$. The intensity of the absorption maximum at $\lambda=478 \mathrm{~nm}$ gradually decreases, at the same time a new band appears at $\lambda=548 \mathrm{~nm}$. This acidic form corresponds to a concentration of $\mathrm{H}_{2} \mathrm{SO}_{4}$ equal to $2.8952 \mathrm{~mol} \cdot \mathrm{L}^{-1}$.

An increase in the amount of $\mathrm{H}_{2} \mathrm{SO}_{4}$ to $15.4098 \mathrm{~mol} \cdot \mathrm{L}^{-1}$ leads to a decrease of intensity at $\lambda=548 \mathrm{~nm}$, a further bathochromic shift of the absorption maximum on $166 \mathrm{~nm}$, and the appearance of a broadened band at $\lambda=716 \mathrm{~nm}$, indicating a stronger acid-base interaction 1 in the $\mathrm{C}_{2} \mathrm{H}_{5} \mathrm{OH}-$ $\mathrm{H}_{2} \mathrm{SO}_{4}$ medium as compared to $\mathrm{CH}_{2} \mathrm{Cl}_{2}-\mathrm{CF}_{3} \mathrm{COOH}$.

We could not calculate the concentration and thermodynamic stability constants for a given medium, since already in the first stage of protonation at concentrations of sulfuric acid $0.3596-2.8952 \mathrm{~mol} \cdot \mathrm{L}^{-1}$, several processes occurred simultaneously, which can be related either with the phenomenon of homoconjugation, or with intermolecular and chemical interaction of solvents. This study allowed only to determine the intervals of acid concentrations at which acid forms appear.

It should be noted that compound $\mathbf{1}$ has unique optical properties that allow the position of the absorption maximum in the visible region of UV-Vis spectrum to be changed by adding an acid or base to the solution of the compound in an organic solvent, i.e. to convert a non-protonated form into a protonated form, and vice versa. It is important that destruction of $\mathbf{1}$ is not observed, which is not characteristic for compounds of this type. ${ }^{[12]}$ Such acid-base interactions make it possible to classify this product as "molecular chameleon", i.e. a compound that has a unique potential for postsynthetic modification of the optical properties of the molecule (Figure 11). ${ }^{[13]}$

Theoretically, there are four intra-cyclic nitrogen atoms from the isoindole and thiadiazole fragments and four bridging meso-nitrogen atoms of the macrocyclic ring in compound 1 which can act as donor centers for proton addition. To determine of the most probable location of the proton addition, we performed a theoretical study of the model compound (4), the structural formula of which is shown in Figure 12 , the numbers denote the places of probable addition

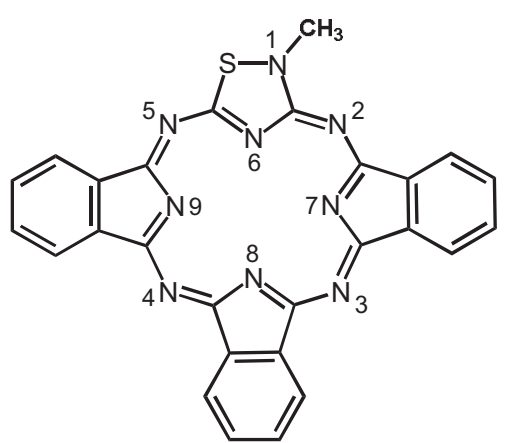

Figure 12. The structure of model compound 4.

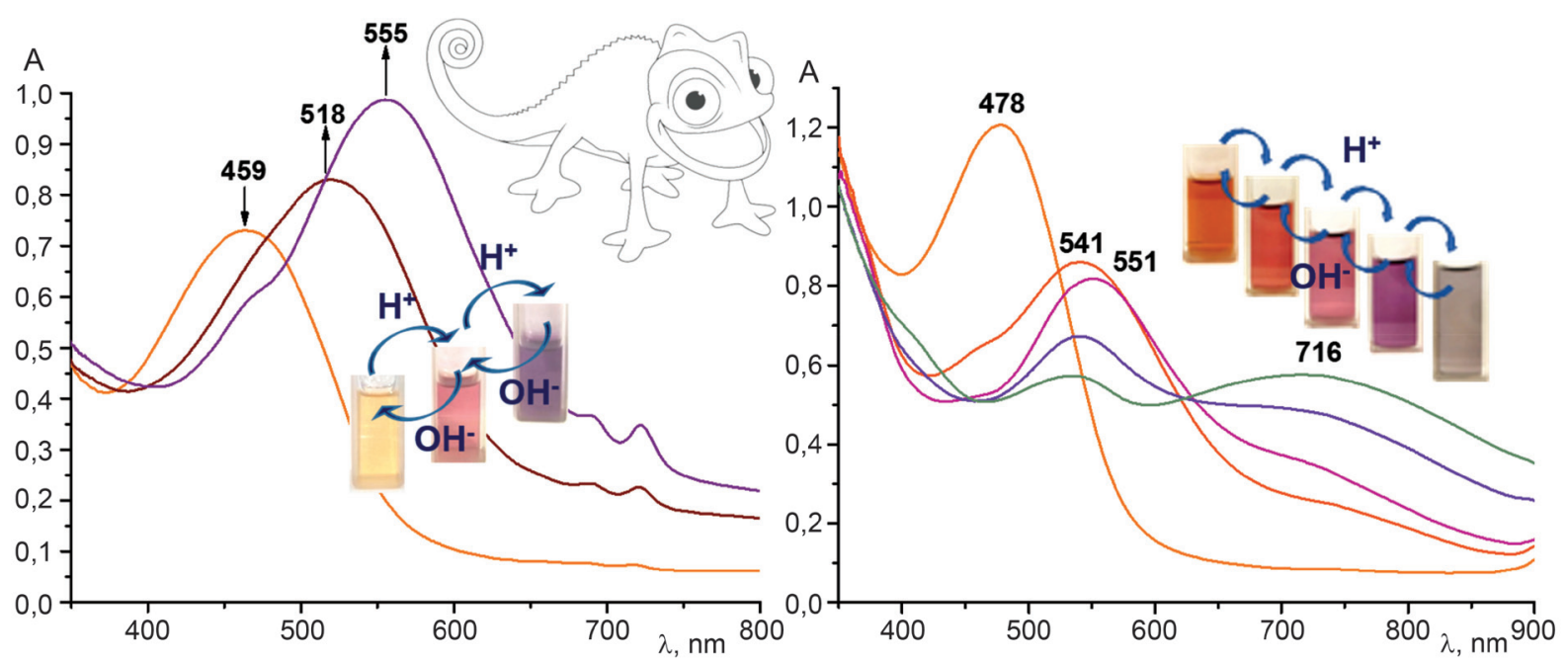

Figure 11. Changes of the UV-Vis spectrum of compound 1 at adding of acid or base by solution: a) in $\left.\mathrm{CH}_{2} \mathrm{Cl}_{2}, b\right)$ in $\mathrm{C}_{2} \mathrm{H}_{5} \mathrm{OH}$. 
of the proton. To simplify the calculations, methyl is chosen as the alkyl substituent.

As mentioned above, according to spectrophotometric titration, one molecule of acid participates in protonation in the first stage. In this regard, complete optimization of the geometric parameters of all possible monoprotonated configurations by the semi-empirical AM1 method with further refinement by the DFT method using the B3LYP hybrid functional and the $6-31 \mathrm{G}(\mathrm{d}, \mathrm{p})$ basic set was carried out. According to the results of the calculations, the most energetically favorable configuration is the one in which the proton addition takes place at position 8, i.e. along the intra-cyclic nitrogen atom of the isoindole fragment located opposite the thiadiazole ring (Table 1).

Table 1. The calculated values of the total and relative energies of monoprotonated configurations.

\begin{tabular}{|c|c|c|c|}
\hline \multirow{10}{*}{ 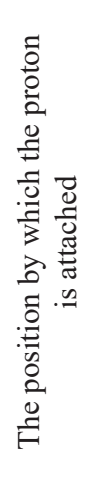 } & Atom number & $E_{\text {total }}, \mathrm{kcal} \cdot \mathrm{mol}^{-1}$ & $\Delta E, \mathrm{kcal} \cdot \mathrm{mol}^{-1}$ \\
\hline & 1 & -1209998.06 & 59.51 \\
\hline & 2 & -1210023.62 & 33.96 \\
\hline & 3 & -1210033.06 & 24.51 \\
\hline & 4 & -1210033.40 & 24.17 \\
\hline & 5 & -1210025.74 & 31.83 \\
\hline & 6 & -1210040.69 & 16.88 \\
\hline & 7 & -1210055.04 & 2.54 \\
\hline & 8 & -1210057.57 & $\mathbf{0}$ \\
\hline & 9 & -1210055.30 & 2.27 \\
\hline
\end{tabular}

\section{Conclusions}

Thus, we synthesized ABBB-type macroheterocyclic compound containing the 5-amino-2-dodecyl-3-imino1,2,4-thiadiazoline fragment. This compound has unique acid-base properties and can be used as indicator of acidbase processes. It was shown by ${ }^{1} \mathrm{H}$ NMR spectroscopy that the target product did not form the expected tatraazachlorin similar structure.

Acknowledgments. The work was carried out by support of Russian Scientific Fund (agreement 14-23-00204P).

\section{References}

1. Gamayunov S., Turchin I., Fiks I., Korchagina K., Kleshnin M., Shakhova N. Photonics and Lasers in Medicine 2016, 5, 101-111.

2. Rudenko T.G., Shekhter A.B., Guller A.E., Aksenova N.A., Glagolev N.N., Ivanov A.V., Aboyants R.K., Kotova S.L., Solovieva A.B. Photochem. Photobiol. 2014, 90, 1413-1422.

3. Veselkina O.S., Solovtsova I.L., Petrishchev N.N., Galebskaya L.V., Borovitov M.E., Nilov D.I., Solov'eva M.A., Vorob'ev E.A., Len'shina K.S. Pharm. Chem. J. 2016, 49, 743-748.

4. Patent RF 2548726, 2015.

5. Whitlock H.W., Hanauer Jr.R., Oester M.Y., Bower B.K. J. Am. Chem. Soc. 1969, 91, 7485-7489.

6. Butina Yu.V., Kudayarova T.V., Danilova E.A., Semenishin N.N. Izv. Vyssh. Uchebn. Zaved. Khim. Khim. Tekhnol. 2016, 59(10), 36-40.

7. Khelevina O.G., Romanenko Yu.V., Islyaikin M.K. Russ. J. Coord. Chem. 2006, 32, 121-125.

8. Islyaikin M.K., Trukhina O.N., Romanenko Yu.V., Danilova E.A., Khelevina O.G. Macroheterocycles 2008, 1, 30-39.

9. Danilova E.A., Melenchuk T.V., Trukhina O.N., Zakharov A.V., Islyaikin M.K. Macroheterocycles 2010, 3, 33-37.

10. Melenchuk T.V., Danilova E.A., Islyaikin M.K. Russ. J. Gen. Chem. 2010, 80, 1369-1372 (in Russ.).

11. Trukhina O.N., Rodríguez-Morgade M.S., Wolfrum S., Caballero E., Snejko N., Danilova E.A., Gutiérrez-Puebla E., Islyaikin M.K., Guldi D.M., Torres T. J. Am. Chem. Soc. 2010, 132, 12991-12999.

12. Romanenko Yu.V. Diss. cand. chem. sci. Ivanovo: ISUCT, 2007. 118 p. (in Russ.).

13. Safonova E.A., Martynov A.G., Nefedov S.E., Kirakosyan G.A., Gorbunova Y.G., Tsivadze A.Yu. Inorg. Chem. 2016, 55, 2450-2459. 